\title{
STUDI FENOMENOLOGI PERSEPSI WANITA USIA SUBUR TENTANG PERAWATAN VAGINA DI PEMALANG
}

\author{
Siti Nur Umariyah Febriyanti ${ }^{1)}$, Rahayu Endang Palupi ${ }^{2)}$ \\ ${ }^{1}$ snu.febriyanti@gmail.com, ${ }^{2}$ palupiendang23@gmail.com \\ $\left.{ }^{12}\right)$ Prodi D IV Kebidanan STIKes Karya Husada Semarang \\ J1. Kompol R Soekanto No. 46 Semarang
}

\begin{abstract}
Abstrak
Perawatan vagina adalah istilah yang mencakup berbagai perilaku yang dilakukan untuk berbagai motif, dengan melakukan beberapa tindakan pada pada labia, klitoris, vagina atau daerah vaginal. Alasan besar wanita melakukan perawatan vagina yaitu untuk meningkatkan hubungan seksual, vagina rapet dan keset. Di Indonesia peningkatan jumlah salon penyedia layanan perawatan vagina meningkat. Sebagian besar persepsi wanita tentang perawatan vagina masih keliru, sehingga perlu dilakukan penelitian yang mendalam tentang persepsi wanita terhadap perawatan vagina. Penelitian ini bertujuan untuk mengeksplorasi persepsi wanita usia subur tentang perawatan vagina di Salon" L" Pemalang. Desain penelitian yang digunakan penelitian Kualitatif dengan pendekatan fenomenologi. Partisipan penelitian ini adalah Wanita Usia Subur usia 28-35 tahun, sudah menikah, dan pernah melakukan perawatan vagina minimal 3 kali. Menentukan jumlah populasi dengan saturasi data. Instrumen dalam penelitian ini adalah peneliti sendiri dan panduan wawancara.Hasil penelitian menunjukkan bahwa pemahaman Wanita Usia Subur tentang pengertian perawatan vagina, jenis-jenis perawatan, waktu pelaksanaan perawatan vagina, manfaat perawatan vagina dan alasan wanita melakukan perawatan vagina masih keliru. Disarankan kepada wanita usia subur lebih memahami tentang perawatan vagina untuk sehari-hari dan cara melakukan personal hygiene yang baik.
\end{abstract}

Kata-kata kunci : Perawatan Vagina; Persepsi Wanita Usia Subur

\begin{abstract}
Vagina Treatment is a term that covers a range of behaviors that made for a variety of motives, by taking some action on the labia, clitoris, vagina or vaginal area. Big reasons that women do vagina care are to enhance sexual intercourse, tight and rigid vagina. In Indonesia the number of beauty shop that accommodating vaginal care service are increased. Most of the women's perceptions about vagina care are still wrong, so we need a deep study on women's perceptions of vaginal care. This study aims to explore the perception of women of childbearing age about the vaginal treatment in " $L$ " Beauty Shop Pemalang. The study design used was qualitative research with phenomenological approach. Participants of this study were women of childbearing age 2835 years of age, married, and never did vagina care at least 3 times. Determining the population with saturation data. Instruments in this study are the researchers itself and interview guides. The results showed that the understanding of women of childbearing age about the vagina care, types of treatments, timing of vaginal treatment, benefits vagina treatment and the reason women do vagina care are still mistaken. Women of childbearing age to understand more about vaginal care for every day and way of doing good personal hygiene.
\end{abstract}

Keywords: The Perception of Women of Childbearing Age, Vaginal Treatment

\section{Pendahuluan}

Persepsi adalah suatu proses rangsangan pada stimulus otak melalui pengindraan dalam menginterpretasikan atau menafsirkan informasi pada suatu objek tertentu. Persepsi juga dapat diartikan sebagai cara pandang individu pada suatu objek tertentu dengan cara yang berbeda-beda menggunakan alat indra yang dimiliki, kemudian berusaha untuk membuat kesimpulan. Berdasarkan hal tersebut hasil persepsi mungkin akan berbeda pada setiap individu. Oleh sebab itu persepsi wanita 
tentang perawatan vagina akan berbedabeda sesuai cara pandang wanita tentang perawatan vagina itu sendiri ${ }^{[1]}$.

Perawatan vagina adalah istilah yang mencakup berbagai perilaku yang dilakukan untuk berbagai motif, dengan melakukan beberapa tindakan pada pada labia, klitoris, vagina atau daerah vaginal. Secara global, ada berbagai macam praktik vagina dan produk yang digunakan oleh wanita untuk mengencangkan, kering, hangat dan membersihkan vagina. Macam-macam dari praktik vaginal yaitu cuci eksternal, intravaginal pembersihan, Aplikasi Eksternal, intravaginal penyisipan, Oral, Vagina Streaming atau merokok, dan modifikasi anatomi.

Wanita dari berbagai belahan bumi di dunia memiliki alasan yang sama untuk melakukan perawatan vagina dengan metode yang berbeda. Alasan yang paling umum antara lain untuk meningkatkan pengalaman seksual dengan sensasi vagina keset, kenceng dan hangat, membersihkan vagina sebelum dan sesudah melakukan hubungan intim, mengobati penyakit kandungan, mencegah penularan dan infeksi kelamin, mengembalikan dan mengencangkan vagina setelah melahirkan

Hasil penelitian dari Adriane Martin Hilber, 2010 yang dilakukan di empat negara yaitu Indonesia (Yogyakarta), Mozambique (Tete), South Africa (Kwazulu-Natal), Thailand (Bangkok). Wanita melakukan perawatan vagina untuk mencapai keadaan vagina yang diinginkan berkaitan dengan perawatan diri sendiri, peningkatan seksual, kesehatan dan kesejahteraan. Kajian ini mengemukaan bahwa wanita dari 4 negara telah mencoba untuk merawat kerapatan, kebersihan dan kondisi hormon vagina dengan menggunakan produk setempat, tradisional, rumah tangga, dan resep modern.

Berdasarkan studi lapangan perawatan vagina dapat ditemukan dengan mudah di berbagai salon kecantikan yang ada, salah satunya di
Salon kecantikan L yang menawarkan berbagai pelayanan dan produk-produk kecantikan, seperti facial, totok wajah, lulur, ratus vagina, body spa dan lainlain. Rata-rata pengguna perawatan vagina pada Salon "L" setiap bulannya sebanyak 30 orang, sedangkan rata-rata umur pengguna perawatan vagina di Salon "L" yaitu 28-35 tahun. Pada studi pendahuluan yang dilakukan dengan mewawancari 6 pelanggan di Salon L tentang pengetahuan perawatan vagina 6 pelanggan mengatakan bahwa perawatan vagina yaitu perawatan pada alat kelamin atau vagina, sedangkan untuk jenis-jenis perawatan vagina 5 wanita hanya mengetahui satu perawatan saja yaitu ratus vagina, sedangkan 1 pelanggan mengatakan douching dan ratus, untuk manfaat perawatan vagina 6 pelanggan mengatakan untuk terhindar dari keputihan, supaya vaginanya keset, dan suami tambah cinta. Sedangkan pada saat diwawancara tentang waktu pelaksanaan perawatan vagina 4 pelanggan mengatakan perawatan vagina dilakaukan sesudah selesai menstruasi dan pada saat keputihan, sedangkan 2 pelanggan mengatakan pada saat diinginkan saja. Alasan dari 6 pelanggan ini melakukan perawatan vagina yaitu supaya vagina rapet, keset, tidak bau dan tidak keputihan serta tambah disayang suami. Sebagian besar pelanggan mengatakan bahwa awal mula melakukan perawatan vagina karena mendapat informasi dari temanteman yang sudah melakukan perawatan vagina, serta banyaknya penyedia layanan perawatan vagina di salonsalon, sehingga itu memudahkan wanita melakukan perawatan vagina.

Dari hasil wawancara dapat disimpulkan bahwa alasan wanita dalam melakukan perawatan vagina yaitu vagina menjadi rapet, keset, tidak bau, tidak keputihan dan supaya tambah disayang suami. Pada hasil wawancara ini juga ada beberapa faktor yang mempengaruhi seseorang berperilaku terdapat faktor penentu yaitu pengetahuan wanita itu sendiri tentang perawatan vagina, faktor pendukung 
dilihat dari sebagian wanita mengatakan melakukan perawatan vagina karena ada tempat pelayanan perawatan vagina, malu untuk periksa ke tenaga kesehatan dan faktor pendorong dari temen yang sudah melakukan perawatan vagina ${ }^{[2]}$. Hal ini sesuai dengan teori Lawrence Green, 2007 mengenai teori perubahan perilaku yang dapat menentukan pengambilan keputusan dalam melakukan perawatan vagina. Sebagian besar persepsi wanita tentang perawatan vagina masih keliru, sehingga perlu dilakukan penelitian yang mendalam tentang persepsi wanita terhadap perawatan vagina. Penelitian ini juga bertujuan untuk melihat apakah perawatan vagina sebagai hal yang rutin dilakukan, faktor tradisi yang ada atau memang karena terbukti bermanfaat sesuai dengan mitos yang berkembang di masyarakat. Melihat fenomena tersebut peneliti tertarik untuk melakukan penelitian "Studi fenomenologi presepsi wanita usia subur terhadap perawatan vagina".

\section{Metode Penelitian}

Penelitian ini menggunakan metode penelitian kualitatif dengan pendekatan fenomenologi untuk mengeksplorasi persepsi wanita usia subur tentang perawatan vagina di Salon" L" Pemalang. Partisipan penelitian ini adalah wanita usia subur usia 28-35 tahun, sudah menikah, dan pernah melakukan perawatan vagina minimal 3 kali. Menentukan jumlah populasi dengan saturasi data. Jumlah partisipan pada penelitian ini sebanyak 3 orang. Instrumen dalam penelitian ini adalah peneliti sendiri dan panduan wawancara. Tehnik pengumpulan data yang digunakan dalam penelitian ini adalah dengan menggunakan wawancara mendalam (in-depth interview). Pada metode ini, pengumpulan data dilakukan dengan metode tanya jawab (dialog) langsung antara peneliti dengan partisipan. Alat yang digunakan membantu kelancaran pengambilan data yaitu pedoman wawancara, alat perekam dan alat tulis.

\section{Hasil dan Pembahasan}

a. Pengetahuan wanita usia subur tentang perawatan vagina

Hasil wawancara didapatkan bahwa pemahaman partisipan tentang pengertian perawatan vagina masih keliru. Perawatan vagina menurut mereka yaitu perawatan pada daerah vagina untuk membersihkan vagina dengan sabun pencuci vagina atau dengan melakukan perawatan vagina untuk menyembuhkan atau mencegah keputihan.

Hasil wawancara dari partisipan dan triangulasi 1 sesuai dengan hasil penelitian WHO Tahun 2012 tentang perawatan seksualitas dan perawatan vagina yang dilakukan oleh empat Negara yaitu Indonesia, Tete, South Afrika dan Bangkok. Dari hasil penelitian ini perawatan vagina yang banyak digunakan yaitu teknik pengasapan sebanyak $67 \%$ dari dua pertiga perempuan bangkok sedangkan $86 \%$ wanita asia melakukan perawatan vagina tradisional pada masa postpartum. Alasan besar wanita melakukan perawatan vagina sebanyak $64 \%$ pengguna beralasan untuk meningkatkan hubungan seksual, kesenangan, membersihkan vagina dan membuat vagina lebih rapat. Sedangkan untuk alasan pengeringan sebanyak $23 \%$ pengguna $^{[3]}$.

Alasan wanita melakukan ratus vagina yaitu untuk menjaga kebersihan vagina, mengencangkan otot vagina, meningkatkan hubungan seksual dan kepercayaan diri bertambah $^{[4]}$. Di Indonesia peningkatan jumlah salon penyedia layanan pengasapan vagina dengan herbal sebagai bagian dari inovatif perawatan kecantikan ${ }^{[1]}$.

Dalam penelitian ini dapat dianalisa bahwa persepsi wanita usia subur tentang pengertian perawatan vagina ini bervariasi dilihat dari hasil wawancara. Ini dikarenakan pendapat atau cara pandang mereka tentang perawatan vagina yang berbeda-beda 
sehingga menghasilkan jawaban yang bervariasi. Diharapkan wanita usia subur tidak hanya tahu tentang pengertian perawatan vagina saja, tetapi mengetahui bagaimana melakukan cara merawat vagina sehari-hari.

Ada beberapa cara perawatan vagina antara lain : 1) Membersihkan daerah kewanitaan yang baik ialah membasuh dengan air bersih, terutama setelah buang air besar (BAB) dan buang air kecil (BAK), yaitu dengan membasuhnya dari arah depan ke belakang(dari vagina kearah anus) 2) Usahakan daerah kewanitaan dalam keadaan kering, terpenting mengeringkan daerah di sekitar vagina dengan menggunakan tissu ataupun handuk kecil setelah membasuh 3) Hindari celana dalam yang ketat dan usahkan celana dalam dengan bahan katun yang dapat menyerap keringat 4) Apabila menggunakan sabun untuk membersihkan daerah kewanitaan sebaiknya gunakan pembersih vagina dengan $\mathrm{pH}$ 3,8-4 dan jangan terlalu sering menggunakan pembersih vagina $^{[5]}$.

\section{b. Jenis-Jenis Perawatan Vagina}

Hasil wawancara didapatkan hasi dari 3 partisipan, bahwa pemahaman tentang jenis-jenis perawatan vagina masih keliru, menurut mereka jenis perawatan vagina ada dua macam, yaitu perawatan vagina ratus uap dan perawatan vagina pembakaran. Hal ini diperkuat dengan pernyataan $\mathrm{T} 1$ yaitu pemilik salon bahwa perawatan yang ada di salon L hanya ada 2 macam jenis, yaitu ratus uap dan ratus pembakaran. Alasan T1 pemilik salon menyediakan perawatan ratus karena ratus yaitu perawatan tanpa resiko, karena dilakukan di luar vagina. Tetapi menurut pandangan T2 bahwa perawatan vagina seperti ratus juga memiliki dampak resiko kurang baik bagi daerah kewanitaan, khususnya pada penggunaan bahan ratus yang sudah jadi yang belum tahu kandungan dan dosisnya sehingga hal ini dapat menyebabkan dampak resiko yang kurang baik. Dan lebih disarankan untuk melakukan perawatan personal hygine.

Menurut World Health Organization (WHO) jenis perawatan vagina bermacam-macam dari paraktik vaginal yaitu cuci eksternal, intravaginal pembersihan, Aplikasi Eksternal, intravaginal penyisipan, Oral, Vagina Streaming atau merokok, dan modifikasi anatomi. Dapat dianalisis dari hasil penelitian ini sudah melakukan satu dari jenisjenis perawatan vagina yang telah disebutkan oleh WHO, khususnya pada perawatan vagina ratus (streaming atau merokok). Ramuan ratus ini terdiri dari tumbuhan herbal, rempah dan akar tumbuh-tumbuhan seperti teh hijau, cempaka, mawar, melati, yang kemudian dikeringkan. Bukan saja membersihkan dan mengharumkan, gurah vagina juga bisa untuk menghilangkan keputihan ${ }^{[3]}$.

Berdasarkan hasil penelitian ini dapat dianalis bahwa pengetahuan partisipan dan T1 (Pemilik salon) tentang jenis-jenis perawatan vagina hanya ratus uap dan ratus pembakaran, sedangkan menurut T2 (Dokter SpOG) bahwa jenis perawatan vagina hanya pada personal hygine saja. Dari hasil analisis diharapkan wanita usia subur mengetahui tentang bagaimana melakukan perawatan vagina dengan personal hygine yang baik, sehingga tidak perlu melakukan perawatan yang mengakibatkan dampak yang kurang baik bagi daerah kewanitaan.

c. Manfaat dari perawatan vagina

Hasil penelitian didapatkan bahwa pemahaman wanita usia subur (WUS) tentang manfaat langsung yang didapatkan setelah melakukan perawatan ratus masih keliru. Partisipan 1 dan 3 menggatakan 
bahwa setelah melakukan perawatan ratus vagina, vagina terasa bersih, keset, rapet dan wangi. Sedangkan partisipan 2 mengatakan bahwa setelah melakukan perawatan ratus vagina terasa keset, wangi dan menyembuhkan keputihan yang dialaminya. Hal ini diperkuat dengan pernyataan triangulasi 1 (pemilik salon) bahwa manfaat langsung yang didapatkan setelah melakukan perawatan vagina yaitu vagina terasa keset, rapet, wangi dan dapat menyembuhkan keputihan.

Manfaat perawatan vagina antara lain mengharumkan vagina karena menggunakan ramuan tradisional yang aman, menghilangkan jamur penyebab gatal dan bau yang tidak sedap sehabis menstruasi, meningkatkan gairah seksual, mengurangi keputihan yang abnormal, mengencangkan otot vagina vagina setelah melahirkan, mengurangi lendir yang berlebihan ketika berhubungan seksual dan mengurangi kejang otot pada daerah vagina saat berhubungan seksual ${ }^{[4]}$.

Hasil dari wawancara T1, T2 dan $\mathrm{T} 3$ tentang masalah yang dialami pada daerah kewanitaan seperti keputihan, tiga partisipan mengatakan tidak pernah mengalami masalah keputihan yang terus menerus, mereka hanya mengatakan mengalami keputihan jika sesudah haid atau pun pada saat lelah saja. Hal ini diperkuat dengan pernyataan T1 (pemilik salon), bahwa klien yang melakukan perawatan vagina ratus biasanya karena mereka ingin merawat daerah vagina saja, tetapi ada juga klien yang datang karena mengalami keputihan, sehingga melakukan perawatan ratus vagina.

Dalam penelitian ini dapat dianalisa bahwa manfaat setelah melakukan perawatan vagina yang dirasakan partisipan yaitu membuat vagina lebih rapat, keset, wangi dan dapat menyembuhkan keputihan yang dialami. d. Waktu pelaksanaan perawatan vagina

Hasil wawancara dari 3 partisipan, 3 partisipan mengatakan bahwa saran dari petugas salon untuk melakukan perawatan vagina yaitu 1 bulan sekali sesudah haid, tetapi jika mengalami keputihan biasanya petugas salon menyarankan untuk melakukan perawatan ratus 1 minggu sekali.

Hasil penelitian tentang waktu pelaksanaan perawatan vagina, P2 dan P3 mengatakan melakukan perawatan ratus sesudah haid dan pada saat mengalami keputihan. Sedangkan P1 mengatakan melakukan perawatan ratus setelah haid saja. Syarat penggunaan ratus dilakukan 1 bulan sekali setelah haid, dua minggu sekali, tidak sedang haid, tidak menderita penyakit kelamin, dan berusia 20 tahun keatas. Dalam teori Asfiani tidak menganjurkan untuk melakukan ratus terlalu sering karena hal ini akan berdampak kurang baik bagi daerah kewanitaan yang dapat mempengaruhi flora-flora normal dalam vagina ${ }^{[6]}$.

Sedangkan menurut hasil penelitian WHO dan ICRH (Internantional Center For Reproductive Health) Perawatan vagina dapat beresiko lebih tinggi dalam penularan infeksi menular seksual, seperti HIV. Dalam penelitian ini menyebutkan bahwa perawatan vagina yang dianjurkan yaitu dengan cara personal hygine yang bagus. Hal tersebut menjelaskan bahwa, perawatan vagina akan mengganggu keadaan lingkungan vagina normal karena justru lingkungan ber-PH asam adalah yang diperlukan untuk kelangsungan hidup Lactoba-cilli (flora baik dalam vagina). Teknik perawatan vagina dapat mengubah flora vagina normal menjadi flora patogen yang dapat menciptakan kondisi menguntungkan bagi penularan infeksi menular seksual (IMS), termasuk HIV ${ }^{[3]}$.

Selama periode reproduksi pada wanita dengan tingkat estrogen yang 
mencukupi, lactobacillus merupakan flora normal yang paling dominan $(>95 \%)$ hidup dan berkembang biak dalam vagina, dan selebihnya adalah bakteri patogen. Dalam kondisi seimbang bakteri pathogen ini tidak akan mengganggu ${ }^{[5]}$. Pada kondisi normal $\mathrm{pH}$ vagina keasamannya dipertahankan oleh adanya Lactobacillus yaitu Bacillus doederlin. Bakteri ini mengubah glikogen menjadi asam laktat yang berfungsi mempertahankan $\mathrm{pH}$ vagina agar tetap dalam kondisi asam (3.8-4.5). Hal ini bertujuan untuk mencegah berkembangnya bakteri patogen dalam vagina. Dengan tingkat keasaman tersebut, laktobasilus akan subur dan bakteri patogen tidak bisa hidup. Banyak faktor yang menyebabkan ketidakseimbangan $\mathrm{pH}$ vagina, antara lain kontrasepsi oral, diabetes mellitus, pemakaian antibiotik, darah haid, cairan mani, penyemprotan cairan ke dalam vagina (douching) dan gangguan hormon ${ }^{[7]}$.

Dalam penelitian ini dapat dianalisa bahwa waktu pelaksanan perawatan vagina dapat mempengaruhi keadaan $\mathrm{pH}$ vagina vagina, semakin sering melakukan perawatan vagina maka semakin berdampak tidak baik untuk floraflora normal pada vagina. Sehinggal hal ini diharapkan wanita usia subur lebih mengetahuai cara perawatan vagina dengan memperbaiki personal hygine yang baik dan benar, sehinggal hal ini dapat mencegah terjadinya masalah-masalah pada daerah vagina.

Apabila $\mathrm{pH}$ naik diatas 5, maka insiden infeksi pada vagina akan meningkat. Cairan yang terus mengalir dari vagina berfungsi untuk mempertahankan kebersihan relatif vagina serta sebagai mekanisme pertahanan dari berbagai macam infeksi ${ }^{[7]}$.

Vagina sebenarnya telah memiliki suatu mekanisme alami yang akan mempertahankan keseimbangan keasaman vagina. Mekanisme ini diperankan oleh bakteri normal yang secara alami terdapat di dalam vagina. Apabila keseimbangan tersebut terganggu, bakteri ini akan mati dan justru menyebabkan perkembangbiakan bakteri patogen yang dapat menimbulkan penyakit.

\section{Kesimpulan}

Pemahaman wanita usia subur tentang perawatan vagina masih keliru yaitu perawatan dengan melakukan spa di salon-salon seperti ratus vagina, yang bertujuan untuk membersihkan vagina, agar vagina lebih keset, rapet, wangi dan dapat menyembuhkan keputihan yang dialami, pemahaman yang keliru tentang manfaat yang diperoleh setelah melakukan perawatan vagina seperti, vagina lebih keset, wangi, dan keputihan berkurang, pelaksanaan perawatan vagina masih keliru yaitu dilakukan setiap 1 bulan sekali atau ketika mengalami keputihan, alasan melakukan perawatan vagina masih keliru yaitu untuk meningkatkan kepercayaan diri pada saat berhubungan seksual, membersihkan vagina, agar vagina keset, rapet dan menyembuhkan keputihan.

\section{Ucapan terima kasih}

Peneliti mengucapkan terima kasih kepada UP3M STIKes Karya Husada Semarang, partisipan (Wanita Usia Subur) dan pemilik Salon "L" di Pemalang atas terselenggaranya penelitian ini

\section{Daftar Pustaka}

[1] Walgito, Bimo. Pengantar Psikologi Umum. Yogyakarta: C.V Andi Offset. 2010.

[2] Green, Lawrence W \&Kreuter, M.W. Health promotion planning. U.S : Mayfield Publishing Company. 1991.

[3] WHO. A multi-country study on gender, sexuality and vaginal practices.http://www.who.int/repr oductiveheakth/publication/sexual 
_health/rhr_12_15/en.Diakses

pada tanggal: 24 Mei 2016. 2012.

[4] Kinasih, Neyla. Wanita Pintar

Kesehatan dan Kecantikan.

Bantul: Araska. 2012.

[5] Pribakti B. Tips Dan Trik Merawat Organ Intim. Jakarta. Sagung Seto. 2010.

[6] Asfiani, H. Beauty SPA di Rumah. Octopus. Jakarta. 2011.

[7] Wijayanti Daru. Fakta Penting Seputar Kesehatan Reproduksi Wanita. Yogyakarta: Book Marks. 2009. 